\title{
DESAIN KOMUNIKASI VISUAL DAN MORALITAS
}

\author{
Risvi Pangestu ${ }^{1)}$, Mukhsin Patriansah ${ }^{2}$ \\ 1), 2) Program Studi Desain Komunikasi Visual Universitas Indo Global Mandiri \\ Jl. Jend. Sudirman No. 629 KM.4 Palembang Kode Pos 30129 \\ Email:risvi@uigm.ac.id ${ }^{1)}$, Mukhsin_dkv@uigm.ac.id ${ }^{2)}$
}

\begin{abstract}
Along with the times, morality always has a relationship between humans and other humans. Morality is a moral trait or the overall principles and values relating to good and bad. In art, morality is not fully related to aesthetic considerations, but rather to consider the pros and cons of a work. Each scientific field group must have moral values that must be maintained by every professional actor. For visual communication designers, choosing to frame questions about ethics based on the community related to clients, becomes a dilemma that can encourage a designer to be able to provide the best results, but not by guaranteeing the success of the work for the wider community other than the client. In the design business, the client is often referred to as the main king who must be obeyed and defended. In a different position, the act of honesty of a visual communication designer, is in the tertiary area of a design business. This phenomenon continues to spread coupled with the phenomenon of illegal behaviors carried out by Visual Communication Design practitioners who often distance themselves from the theory that should be applied. The discussion of this study is about how visual communication design is able to achieve moral impact in society through the designer's perspective. This study will be benchmarked on the theoretical design of visual communication and design ethics. Through case studies of advertisements and the approach of design figures who are able to work in their optimal capacity. The understanding of this study is expected to be a consideration for a designer to be able to create the right correlation between morals and design.
\end{abstract}

Keywords : Visual Communication Design, Morality, Design Ethics, Design Bussiness

\begin{abstract}
Abstrak
Seiring perkembangan zaman, moralitas selalu memiliki hubungan antara manusia dengan manusia lainnya. Moralitas merupakan sifat moral atau keseluruhan asas dan nilai yang berkenaan dengan baik dan buruk. Dalam seni, moralitas tidak terkait secara utuh dengan pertimbangan estetis, akan tetapi lebih kepada mempertimbangkan baik buruk sebuah karya. Setiap kelompok bidang keilmuan harus memiliki nilai moral yang harus dijaga oleh setiap pelaku profesi. Bagi desainer komunikasi visual, memilih membingkai pertanyaan seputar etika berdasarkan masyarakat yang berhubungan dengan klient, mampu menciptakan rasa dilematis desainer yang mampu mendorong seorang desainer untuk dapat memberikan hasil terbaik, akan tetapi tidak dengan memberikan jaminan keberhasilan dari karya tersebut untuk masyarakat luas selain klientnya. Dalam bisnis desain, klient seringkali disebut sebagai raja utama yang harus dituruti dan dibela. Diposisi yang berbeda, tindak kejujuran desainer komunikasi visual, berada di wilayah tersier dalam sebuah pengkaryaan bisnis desain. Fenomena tersebut terus merebak ditambah dengan fenomena mengenai perilakuperilaku ilegal yang dilakukan oleh praktisi-praktisi Desain Komunikasi Visual yang seringkali menjauhkan diri dari teoretis yang seharusnya diterapkan. Pembahasan kajian ini mengenai bagaimana desain komunikasi visual mampu mencapai dampak moral dalam masyarakat melalui perspektif desainer. Kajian ini akan betolak ukur pada teoretis desain komunikasi visual dan etika desain. Melalui studi kasus iklan dan pendekatan tokoh-tokoh desain yang mampu berkarya dalam kapasitas optimal diri. Pemahaman kajian ini diharapkan dapat menjadi pertimbangan seorang desainer untuk mampu menciptakan korelasi yang tepat antara moral dan desain.
\end{abstract}

Kata Kunci : Desain Komunikasi Visual, Moralitas, Etika desain, Bisnis Desain 


\section{Pendahuluan}

Revolusi industri menjadikan bidang keilmuan desain komunikasi visual semakin menguat dibenak masyarakat. Proses bisnis desain mengenai jasa desain yang diinginkan oleh klient dan proses penciptaan sebuah hasil karya yang mampu memberikan keuntungan lebih pada klient. Desainer komunikasi visual yang mampu menawarkan jasa Desain Komunikasi Visual harus mampu mempertanggungjawabkan apa yang sudah diciptakan. Wawasan mengenai interdisplin dalam dunia keilmuan desain komunikasi visual menjadi nilai tinggi dari seorang desainer komunikasi visual, untuk dapat menciptakan desain yang bermoral dan bermartabat bagi diri dan lingkungannya. Ditinjau dari bahasanya, moral diambil dari bahasa Latin mos (jamak, mores) yang berarti kebiasaan atau adat. Moralitas adalah sifat moral atau keseluruhan asas dan nilai yang berkenaan dengan baik dan buruk (Bertens 2002:7). Moralitas juga berperan sebagai pengatur dan petunjuk bagi manusia dalam berperilaku agar dapat dikategorikan sebagai manusia yang baik dan dapat menghindari perilaku yang buruk (Keraf, 1993:20). Standar moral yang berlaku di satu tempat dapat berbeda dengan tempat lainnya. Hal inilah yang menyebabkan seseorang dapat dikatakan tidak bermoral apabila tingkah lakukanya berlawanan dengan moralitas yang berlaku dalam masyarakat.

Meskipun moralitas kaitannya bukan dengan pertimbangan estetis, tetapi di dalam seni khususnya bidang desain komunikasi visual, kewajiban memiliki hubungan antara rancangan dengan moralitas adalah keterkaitan yang harus selalu dipertimbangkan. Dalam pertimbangannya, keterkaitan moralitas dalam keilmuan desain komunikasi visual memfokuskan pada hasil karya yang mampu diterima publik dengan sasaran yang tepat. Sasaran ini dapat mengacu pada aspek geografis, demografis, psikografis dan behaviouristik yang menjadi nilai baik dalam beretika desain. Sebuah karya desain dapat menjadi tidak berkesinambungan dengan asas etika desain, diantaranya disebabkan oleh minimnya pendekatan komunikasi antara emosional, rasional, dan moral dalam penciptaan karya tersebut.

Pemahaman mengenai seni secara moralistis dihadirkan kembali melalui Republic tulisan Plato dan mempunyai dukungan paling kuat di zaman modern. Dalam tulisan Plato tersebut mengenai Republic dan Laws, Plato menjelaskan bahwa menurutnya segala imitasi yang tertulis berkaitan dengan tindakan yang jahat merupakan undangan yang secara tidak langsung, untuk meniru tingkah laku itu dalam kehidupan seseorang. Dapat dijelaskan dengan contoh dari segala kisah atau karya sastra mengenai dewa dan pahlawan yang bertingkah laku secara tidak bermoral, harus disingkirkan dari jejak sejarah, sedangkan kisah mengenai para dewa atau pahlawan yang bertindak dengan semestinya dengan kebaikan yang mampu diterima, dituliskan dan diabadikan sehingga lakunya diharapkan dapat diikuti oleh pembaca.
Dalam dunia seni, terdapat gagasan-gagasan yang mampu menembus suatu argumen baku, tingkatantingkatan ortodoksi tertentu dalam masyarakat, melalui karya seni yang dilahirkan. Karya dengan hasil ortodoksi tertentu, memungkinkan adanya gebrakan yang bukan hanya mengganggu kenyamanan, namun juga menggoncang disebuah tatanan dalam bermasyarakat. Pada tatanan yang mapan, hal ini tentu saja dapat menjadi ancaman dan dapat dikategorikan sebagai sebuah tindakan penyimpangan, karena dianggap sebagai penyebab kuat goyangnya suatu keyakinan atau prinsip yang terbentuk di masyarakat. Adanya pemikiran Plato tersebut membuat seni dalam masyarakat tidak lagi hanya berhubungan dengan estetika, namun juga terkait erat dengan kebaikan (moralitas). Dalam pemahaman ini juga, desain komunikasi visual terkhusus secara tidak langsung mampu memiliki kekuatan yang sama untuk mengoyahkan sebuah kebudayaan dalam masyarakat, prinsip yang ditanamkan dalam merancang suatu bentuk penyelesaian masalah harus mampu berhubungan baik dengan moralitas yang menyangkut masyarakat dan lingkungannya. Pertimbangan bisnis desain komunikasi visual dengan moralitas diukur dari sebuah karya yang mampu menjadi desain strategis dengan etika desain yang baik dan benar.

Umumnya, perjalanan etika dan moral selalu dalam sisi yang sama dan beriringan. Dalam pengertiannya, Etika diambil dari bahasa Yunani Kuno "ethikos" yang berarti “timbul dari kebiasaan”. (Bertens 2000:25). Etika dalam hal ini mencakup analisis dan penerapan konsep seperti benar, salah, baik, buruk, dan tanggung jawab. Etika bukanlah perasaan, agama, hukum, penerimaan budaya, norma, maupun pengetahuan. Etika bersumber dari individu pribadi atau dari sebuah komunitas, atau dari sebuah lembaga dan kelompok, oleh karena itulah setiap pribadi memiliki etika, etika dalam diri setiap manusia inilah yang membentuk moral di masyarakat. Etika ini dapat disebut juga dengan cerminan dari moral.

Sama halnya dengan standar moral yang berbeda di tiap tempat, setiap kelompok profesi atau bidang keilmuan memiliki nilai moral berbeda yang harus dijaga oleh setiap pelaku profesinya. Bagi seorang tenaga medis, etika adalah mengenai menjaga pasien agar tetap hidup. Bagi seorang pengacara, etika adalah mengenai bagaimana menjelaskan dan melayani kliennya dengan baik dengan memperjuangkan keadilan bagi manusia. Seorang psikolog menjaga moralnya dengan cara menjaga rahasia cerita kliennya.

Bagi seorang desainer, saat ini, isu etika merupakan isu yang datangnya dari kliennya. Bagi seorang desainer daripada membingkai pertanyaan etis dalam hal bagaimana desainer sendiri dapat berlaku profesional dengan praktik desain yang dilakukannya, desainer lebih memilih membingkai pertanyaan - pertanyaan seputar etika berdasarkan masyarakat yang berhubungan dengan klien, seperti: Apa yang klien lakukan, apakah produk desain dapat diterima secara etis atau tidak oleh klien, dan apakah kepentingan klien terpenuhi dengan produk desain? . Adanya dilematis bagi dunia desainer komunikasi visual ini, bisnis desain menjadi hal yang 
berkaitan dengan moral ataupun etika, yang kemudian menjadi penyebab terhadap dorongan seorang desainer untuk dapat memberikan hasil terbaik namun tidak dapat memberikan jaminan keberhasilan dari hasil tersebut bagi masyarakat yang lebih luas selain kliennya.

Desainer komunikasi visual dimungkinkan telah mengesampingkan aspek moral di masyarakat dan etika dalam dirinya sendiri, sebab hal ini bersentuhan dengan nilai-nilai yang berpotensi bertentangan dari kebebasan pribadinya serta tanggung jawab sosial yang idealnya harus dikerjakan. Preventif dari pemilihan antara keikutsertaan selaku tanggungjawab dalam berbisnis desain dengan pertimbangan dalam menggunakan atau mengesampingkan aspek moral dalam berkarya akan berdampak pada citra seorang desainer komunikasi visual itu sendiri. Tulisan ini akan membahas mengenai moralitas dalam Desain Komunikasi Visual karena saat karya desain diciptakan, karya desain tersebut bukan lagi hanya milik desainernya, namun juga milik kliennya, dan bisa jadi milik masyarakat selain kliennya. Oleh karena itu, perlu diketahui bagaimanakah Desain Komunikasi Visual dapat mencapai dampak moral dalam masyarakat.

\section{Pembahasan}

a. Desain Komunikasi Visual dan Isu Moralitas

Mengenai moralitas dalam Desain Komunikasi Visual ini dapat diawali dengan mengingat seorang desainer bernama Milton Glaser. Pada tahun 1950, Glaser mengungkapkan ketertarikannya untuk bekerja sebagai desainer secara profesional dengan menjaga dirinya dan kliennya berjarak dengan keinginan pribadinya. Namun menurut Glaser, desain grafis atau dikenal dengan desain komunikasi visual pada dasarnya tidak profesional karena akan ada pelanggaran terus menerus (Abraham, 2015).

Pada hari ini desain grafis telah berkembang menjadi Desain Komunikasi Visual. Ditinjau dari teori (Tinarbuko, 2015:5) Desain Komunikasi Visual adalah ilmu yang mempelajari konsep komunikasi dan ungkapan daya kreatif, yang diaplikasikan dalam berbagai media komunikasi visual dengan mengolah elemen desain grafis terdiri dari gambar (ilustrasi), huruf, warna, komposisi, dan layout. Semuanya itu dilakukan guna menyampaikan pesan secara visual, audio, dan audio visual kepada target sasaran yang dituju. Meskipun menghadapi dilema mengenai moral di masyarakat, sebuah artikel di laman Desain Grafis Indonesia mengungkapkan bahwa Desain Komunikasi Visual juga memiliki etika desain, yakni:

1. Benar

Benar artinya, bahan desain harus didasari konsep atau perencanaan berupa latar belakang, masalah tujuan, strategi dan taktik, semua data dikaji dengan faktual, obyektif, proses desain yang diutamakan, memprioritaskan pendekatan kebudayaan, tidak melakukan plagiasi, serta menaati undang-undang hak cipta.

2. Baik
Baik artinya berkaitan dengan estetika. Baik di sini sifatnya lebih subyektif, memenuhi fungsi DKV atau Desain Grafis seperti informatif dan identik, penekanannya pada hasil atau tujuan akhir, cenderung tergantung dengan alat, sifatnya instan, banyak melibatkan konsep komunikasi pemasaran, dapat diterima/komunikatif, hasil karya dapat diterima publik sasaran sesuai dengan aspek geografis, demografis, dan khususnya psikografis sasaran, memasukkan pendekatan komunikasi: emosional, rasional, dan moral, dan sebuah desain harus mampu mendukung peningkatan nilai-nilai.

Ditelaah dari standar etika desain yang telah dirumuskan oleh komunitas Desain Grafis Indonesia tersebut, sebenarnya bidang keilmuan atau praktisi desain komunikasi visual tidak perlu menghadapi dilema mengenai moral dan etika, sebab standar yang telah dirumuskan sangatlah mempertimbangkan moral yang ada dalam masyarakat dan juga mendorong desainer untuk turut membangun moral tersebut dapat berkembang dengan baik melalui etika yang diperjuangkan dari individunya. Namun, pada kenyataannya praktisi-praktisi desain komunikasi visual kini mengesampingkan standar tersebut. Desainer mengerjakan retorika visual untuk mewakili klien tanpa dipengaruhi prinsip pribadinya. Desainer telah banyak memanipulasi dan membujuk.

Berikut ini adalah contoh praktik Desain Komunikasi Visual yang mendapat kecaman dari banyak pihak. Iklan di bawah ini merupakan iklan dari Grab Indonesia, penyedia jasa layanan ojek online di Indonesia.

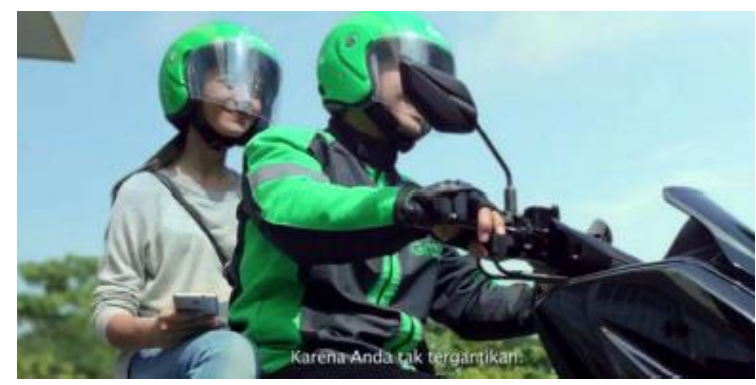

Gambar 1. Iklan Grab \#PilihAman 2018

Iklan tersebut dikecam oleh masyarakat maya Indonesia (netizen) karena dianggap tidak etis dan mengganggu tatanan. Iklan bertajuk \#PilihAman tersebut sempat membuat masyarakat Indonesia kepanasan. Iklan ini berupa video kampanye berdurasi 45 detik yang diunggah Grab lewat channel YouTube-nya pada Minggu, 18 September 2019. Video ini mengantongi jumlah dislikes 1.134 kali, lebih besar ketimbang jumlah yang menge-likes, hanya 976 kali. Video tersebut menceritakan seorang remaja perempuan bernama Dinda, sekilas layar berganti, tampilan iklan mendadak berubah menjadi horor. Sekujur tubuh Dinda berdarah dibalut luka seolah ia mengalami kecelakaan. Dijelaskan lewat voice-over yang menjadi ayah dari Dinda, ia akan menjadi seperti itu (terluka parah) jika memilih transportasi yang tidak aman. Selain itu, ada sebuah adegan yang memperlihatkan Dinda dipanggil oleh 
beberapa pengemudi ojek tradisional di pangkalan. Dinda malah lewat dan memilih membuka aplikasi Grab di smartphone untuk memesan ojek GrabBike. "Pengemudi GrabBike 100 persen lulus pelatihan keselamatan berkendara," tulis kalimat di iklan tersebut. "Karena Anda tak tergantikan," tambah bunyi voice-over di penghujung iklan.

Sebenarnya maksud dan ide besar dari desainer iklan ini hanyalah mengarahkan konsumen untuk menggunakan layanan Grab karena telah terjamin aman dengan adanya lisensi keselamatan. Namun, dalam eksekusi iklannya, ternyata pesan tersebut mengasosiasikan pesan berbeda. Iklan tersebut menuai banyak kecaman dari netizen karena dianggap mengarahkan penonton kepada sebuah pemahaman bahwa ojek pangkalan merupakan moda transportasi yang tidak aman karena tidak memiliki lisensi keselamatan berkendara seperti yang dimiliki pengemudi Grab. Adanya kesalahan pengarahan pesan tersebut disebabkan oleh terjadinya peristiwa yang tidak menyenangkan, yakni perselisihan yang sengit dan berlarut antara pengemudi moda transportasi online dan pengemudi moda transportasi konvensional di Indonesia. Masyarakat menilai iklan ini tidak menampilkan moral yang baik karena dinilai tidak simpatik dengan peristiwa yang terjadi di sekitar terutama tidak menghargai pengemudi ojek konvensional sebagai manusia. Selain itu, visual dengan pendekatan horor dan menampilkan darah dianggap melebih-lebihkan, mengerikan, dan kurang etis untuk ditampilkan ke publik mengingat anakanak di bawah umur pun kini dapat mengakses tayangan di Youtube.

Iklan di atas hanya merupakan salah satu contoh isu moralitas dalam wilayah Desain Komunikasi Visual. Banyak sekali masalah moralitas lainnya, seperti pelanggaran hak cipta, meskipun ini dapat dimasukkan ke ranah hukum, namun secara etika hal tersebut dapat dikatakan sebagai hal yang "tidak baik" untuk dilakukan sebagai praktik profesional. Selain itu di dalam ranah Desain Komunikasi Visual terdapat juga permasalahan seperti pengunduhan elemen-elemen visual dengan ilegal: seperti huruf, aset gambar, foto, dan sebagainya. Kini, desainer komunikasi visual yang bekerja pada media, utamanya media online pun turut serta mengerjakan proyek-proyek media yang cenderung tidak berimbang. Desainer digembar-gemborkan sebagai praktisi yang menghamba pada korporasi atau bekerja dengan berdasarkan permintaan klien saja tanpa mempertimbangkan moral dan etika yang seharusnya diperjuangkan di tengah-tengah masyarakat. Desainer ada dalam sebuah keadaan di mana klien adalah raja yang harus dituruti. Hal ini menambah kenyataan dilematis adalah saat raja tersebut tidak lagi beretika, bagaimana posisi desainer seharusnya dalam masyarakat.

\section{b. Desain Komunikasi Visual dalam Mencapai} Dampak Moralitas

Menurut (Sumardjo, 2000), setiap seniman seperti juga setiap ilmuwan dan filsuf, dituntut untuk bersikap otentik. Jujur pada dirinya sendiri. Sikap ini tidak ada hubungannya dengan ketidakjujuran dalam hidupnya sehari-hari, hal ini hanya berkaitan dengan proses penciptaan karyanya. Desainer komunikasi visual juga sebenarnya sama, seharusnya memang dituntut bersifat otentik terhadap karyanya, jujur pada setiap karya desain yang dikerjakannya. Desainer seharusnya berkarya tidak di bawah kapasitas desainer yang dimilikinya. Desainer seharusnya menguak kebenaran lebih dalam mengenai produk desain yang dikerjakannya, mengenai pesan apa yang akan disampaikannya secara visual, bukan hanya bekerja demi uang, demi nama tenar, ataupun demi persahabatan. Meskipun bekerja di bawah permintaan klien, desainer hendaknya benar-benar menelaah apa yang dikerjakan.

Dalam kaitannya dengan memperjuangkan pencapaian moral dalam masyarakat, sebagaimana John Dewey merumuskan ide dalam Art as Experience, seperti seni, desain juga hendaknya mengajar seperti teman hidup mengajar. Desain seharusnya mengajar bukan dengan moda khotbah dan ceramah namun dengan elemen-elemen visualnya yang dikomunikasikan dan merangkai pesan. Desain dengan fakta fenomena yang ada, data yang telah diolah dengan ilmiah, metode yang kreatif, ditambah dengan elemen visual yang dikerjakan, juga dengan imajinasi sang desainer akan mengungkapkan moral yang baik dalam masyarakat. Desain seharusnya mampu mengungkapkan sebuah perlawanan yang baik dan memperjuangkan keadilan, mengungkapkan kodrat manusia umum yang selama ini bersembunyi di balik dogma dan doktrin yang lebih banyak memecah belah bukan mempersatukan. Desain Komunikasi Visual seharusnya mampu menampilkan secara benar yang seharusnya, namun juga harus mampu menyimpan apa yang tidak pantas dilihat. Hal ini sejalan dengan sebuah ungkapan dari seorang kartunis, Scott Adam, yakni "Creativity is allowing yourself to make mistakes. Art is knowing which ones to keep." Moral yang telah berkembang di masyarakat seharusnya dikritisi, dikaji, diolah dan divisualkan sehingga megajarkan moral yang selalu baru di masyarakat. Desain Komunikasi Visual dan moralitas seharusnya menjadi duet yang seimbang dan melengkapi.

Pada pembahasan berikutnya adalah bagaimana desain dapat mencapai dampak moral dalam masyarakat. Pembahasan mengenai capaian ini, akan dijelaskan melalui pendekatan tokoh-tokoh desain yang mempu berkarya benar-benar dalam kapasitas optimal dirinya dan tidak 'merendahkan' dirinya. Tokoh yang pertama ialah Herb Lubalin dengan karya tipografinya. Herb Lubalin merupakan desainer asal Amerika. Herb berkolaborasi dengan Ralph Ginzburg dalam 3 majalah Ginzburg : Eros, Fact, dan Avant Garde. Majalah Eros (1962-1963) mengabdikan diri pada keindahan mengenai meningkatnya rasa dan eksplorasi seksualitas khususnya dalam budaya tandingan yang berkembang saat itu. Majalah-majalah tersebut melawan sentimen anti kemapanan yang melekat dimana sentimen tersebut tidak dapat diungkapkan melalui media arus utama. Lubalin mengungkapkan wacana mengenai erotisme dengan menggunakan elemen visual berupa tipografi dan tidak 
serta merta menunjukkannya secara gambling menggunakan gambar yang nyata ada. Lubalin menampilkan apa yang secara moral harus dilihat dan apa yang harus disimpan. Namun, karena saat itu hal tersebut masih tabu, majalah Eros harus ditarik peredarannya setelah kasus pencabulan oleh seorang petugas pos Amerika.

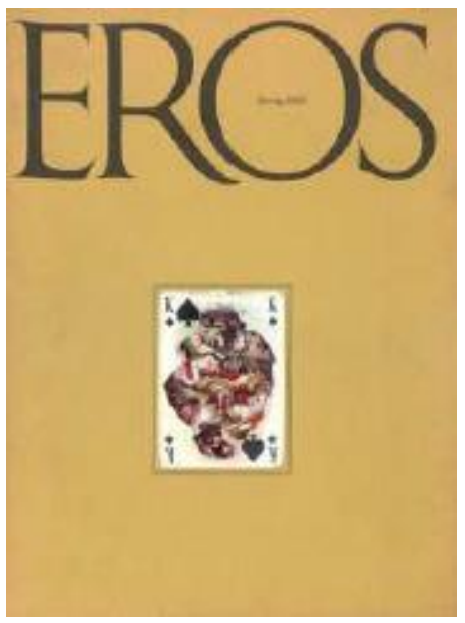

Gambar 2. Majalah Eros - Lubalin

Majalah Facts oleh Lubalin diangkat untuk melawan kemapanan di Amerika, di mana media saat itu mengungkapkan hal-hal manis dengan template desain yang serupa. Lubalin memilih desain yang minimalis dan elegan terdiri dari tipografi serif dinamis yang diimbangi dengan ilustrasi berkualitas tinggi. Majalah tersebut mengkritisi moral namun juga menawarkan sebuah nilai yang baru mengenai keberanian dan perlawanan.

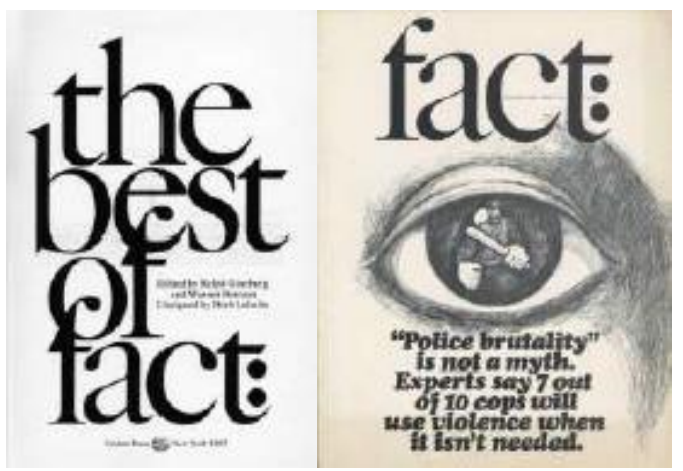

Gambar 3. Majalah Fact: - Lubalin

Tokoh yang kedua adalah Jonathan Barnbrook, seorang desainer dari Inggris yang menawarkan sebuah perlawanan yang mengkritisi ketidakadilan di dunia dengan mengajak para desainer untuk menjauhi perusahaan yang menyuruh mereka berbohong untuk mereka demi uang dan demi keberlanjutan ketidakadilan di dunia. Idealismenya ini diwujudkan melalui desain billboardnya. Billboard tersebut berjudul "Designers Stay Away From Corporation That Want You To Lie for
Them." Ditilik dari tatanan waktu itu tentu saja desain ini kurang baik, namun desain ini menaati kaidah-kaidah desain dan mampu mengemukakan fakta yang jelas nyata terjadi sehingga dapat menawarkan nilai yang baru di masyarakat. Dia telah menyatakan ambisinya untuk menggunakan "desain sebagai senjata untuk perubahan sosial".

Tokoh ketiga berasal dari Indonesia, yaitu Kendra Paramita. Kendra merupakan ilustrator dan desainer grafis senior di Majalah Tempo Indonesia. Ialah sosok di balik setiap sampul ilustrasi jurnalistik majalah Tempo yang menggelitik. Kendra bekerja untuk Tempo secara profesional. Ilustrasi yang dibuatpun berangkat dari berita yang sudah dihimpun oleh jurnalis Tempo.

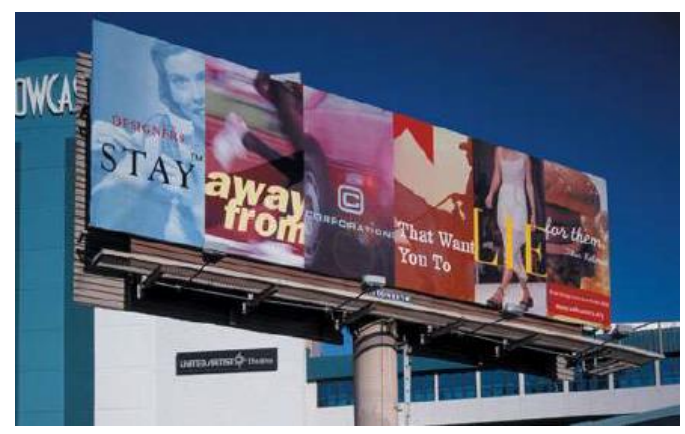

Gambar 4. Designers Stay Away From Corporation That Want You To Lie for Them Billboard ( Barnbrook-2001)

Bagi Kendra, kedalaman cerita dan sudut pandang sangat membantu pengembangan gagasan visual. Kendra selalu berusaha menyampaikan kritik secara visual namun tanpa menyinggung pihak yang dituju. Berikut adalah contoh ilustrasi Kendra dalam Sampul Majalah Tempo.

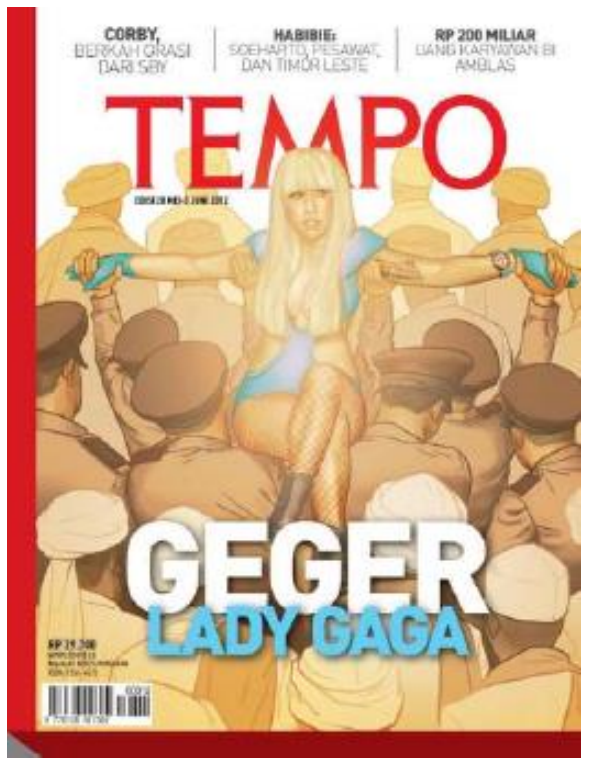

Gambar 5. Geger Lady Gaga-Kendra Paramita (Tempo 29 Mei - 3 Juni 2012)

Desain sampul di atas merupakan sebuah kritik yang bisa dibilang dieksekusi dengan elemen visual yang 
pedas dan bisa juga dibilang tidak pantas karena menampilkan sosok Lady Gaga seorang penyanyi wanita yang kala itu dianggap tidak bermoral sedang digotong oleh Polisi dan ormas agama. Desain sampul di atas mengkritik kejadian mengenai ditolaknya konser Lady Gaga oleh pemerintah Indonesia karena dianggap merusak moral bangsa. Pada ilustrasi ini, Kendra menggunakan elemen-elemen visual dan simbol-simbol 'amoral' untuk menyampaikan sebuah pesan dan pertanyaan mengenai siapa sesungguhnya yang lebih amoral. Kendra memang bekerja di bawah kliennya, sebut saja redaksi Tempo, ia juga mendesain ilustrasi berdasarkan berita yang ada, namun dalam eksekusinya, ia menempatkan idealismenya secara tepat dan baik. Kendra menawarkan sebuah pemahaman baru ke masyarakat mengenai suatu nilai kebenaran yang selama ini disetujui tanpa dikritisi atau dibenarkan tanpa pemahaman mendalam.

Ketiga desainer di atas membuktikan bahwa di tengah isu moralitas dan kisaran permasalahannya dalam praktik Desain Komunikasi Visual, moralitas dan desain itu sendiri dapat saling melengkapi sejauh itu dikiritisi, diterapkan secara spesifik pada media tertentu, dan diolah dengan grafik yang tepat.

\section{Kesimpulan}

Dunia Desain Komunikasi Visual (DKV) telah mengalami gempuran begitu rupa terkait masalah moral dan etika. Banyak hal yang dapat dipertanyakan mengenai bagaimana desainer dan karya desainnya mampu mencapai dampak moral di masyarakat. Selama ini desainer komunikasi visual dikenal dengan hamba klien dimana moral bagi masyarakat luas dikesampingkan. Klien adalah raja utama yang harus dituruti dan dibela. Kejujuran desainer ada di wilayah tersier dalam pengkaryaan. Fenomena tersebut terus merebak ditambah dengan fenomena mengenai perilakuperilaku ilegal yang dilakukan oleh praktisi-praktisi Desain Komunikasi Visual.

Hubungan antara Desain Komunikasi Visual dan moralitas dapat dipelajari menggunakan pendekatan tokoh desain yang menyatakan desainnya dengan spesifik. Ketiga desainer di atas merupakan desainer yang mampu mengkritisi moral yang berkembang di masyarakat namun juga memperkayanya dengan perspektif moralnya sendiri, sehingga dalam masyarakat mereka dapat memberikan pelajaran moral yang tidak menggurui dengan menghadirkan proses berpikir dan berefleksi. Ketiga contoh desainer dan karya desain yang dibahas membuktikan bahwa desain komunikasi visual dan moralitas dapat berjalan beriringan dan saling melengkapi. Desain dan moralitas bukanlah dua hal yang bertentangan, namun merupakan hal yang harus dikritisi, diolah, dan diterapkan dengan spesifik oleh setiap desainer komunikasi visual.

\section{Daftar Pustaka}

Bertens, Kees. 2002. Etika. Jakarta: Penerbit PT Gramedia Pustaka Utama.

Keraf, Sonny. 1991. Etika Bisnis. Yogyakarta: Penerbit Kanisius.

Bertens, Kees. 2000. Etika. Jakarta: Gramedia Pustaka Utama

Tinarbuko, Sumbo. 2015. Dekave: Desain Komunikasi Visual. Yogyakarta: Caps Publishing

Sumardjo, Jakob. 2000. Filsafat Seni. Bandung: Penerbit ITB

Website:

Safanayong, Yongky. 2012. "Etika Desain”. Dalam http://dgi.or.id/read/perspective/etika-desain.html. Diakses 20 September 2021

Abraham, Tim. 2016. "The Only Way is Ethics: What are The Moral Obligations of a Graphic Designer?" Dalam https://www.itsnicethat.com/features/ethicsgraphic-design-essay-131016. Diakses 20 September 2021

Herb Lubalin. http://www.historygraphicdesign.com/theage-of-information/the-new-york-school/681-herblubalin. Diakses 20 September 2021 